\title{
Influence of mixture composition on fresh concrete workability for ballastless track slabs
}

\author{
Liliya Kazanskaya ${ }^{1}$, Olga Smirnova ${ }^{2 *}$ \\ 1 Emperor Alexander I St. Petersburg State Transport University, Moskovsky pr., 9, Saint- \\ Petersburg, 190031, Russia \\ ${ }^{2}$ Saint-Petersburg Mining University, 21 -st Line V.O., 2, Saint-Petersburg, 199106, Russia
}

\begin{abstract}
There are several factors that affect the fresh concrete workability: water demand and composition of Portland cement, properties of fine and coarse aggregates, presence of superplasticizer and others admixtures, etc. Influence of quantity and fineness of ground quartz additives as well as polycarboxylate-based superplasticizer amount on workability of fresh concrete was studied in the paper. The properties of fresh mixture (slump) and hardened concrete (compressive strength at the age of 24 hours, 28 and 360 days) were estimated. Enhancing the fresh concrete workability using fine ground quartz sand was stated. Savings of superplasticizer per $1 \mathrm{~m} 3$ of slab concrete and $1 \mathrm{~km}$ of the ballastless track were calculated.
\end{abstract}

\section{Introduction}

Recently constructions of ballastless track systems are being developed. The superiorities of such structures are: exploitation at high speeds and with heavy loads, structure height reduction; increased service life; high lateral track resistance which allows future speed increases; no problems with churning of ballast particles at high-speed [1-4]. A traditional design, for example such as the RHEDA 2000, consists of slab concrete C 30/37 with thickness of approximately $240 \mathrm{~mm}$, hydraulically bonded layer with thickness of approximately $300 \mathrm{~mm}$, frost protection layer with thickness of approximately $500 \mathrm{~mm}$ and subsoil. The basic system structure has modified bi-block sleepers embedded in a monolithic concrete slab.

Different performance requirements apply to slab concrete as well as hydraulically bonded layer. The slabs can be made as precast concrete or in-situ. The use of efficient construction technology as well as concrete compositions can reduce construction costs. A concrete slab replaces the ballast in the ballastless slab track. This track structure has been used in high-speed railways in Japan, Germany, France and China [5-7]. Currently the most known slab track systems are: Rheda, Züblin and other variants (Germany); Stedef, Sonneville Low Vibration (France); Walo (Switzerland); Edilon block track (Netherlands); Shinkansen slab track (Japan, South Korea); IPA slab track (Italy); ÖBB-Porr (Austria); Embedded Rail Structure (Netherlands); China Railway Track System (CRTS).

\footnotetext{
*Corresponding author: smirnovaolgam@rambler.ru
} 
The slab concrete is the major load-distributing element of the system. It can be individually adapted to any substructure type and condition in case it is cast-in-place. It can be designed as a continuous slab with free crack formation for embankments. The slab can be constructed in unit dimensions of $2.8 \mathrm{~m} \times 0.24 \mathrm{~m}$ for highly compacted soil that is advised for ballastless tracks to prevent settlement. The minimum strength of concrete slab must be $30 / 37 \mathrm{MPa}$ (cube/cylinder) to assure the required durability (Rheda 2000, 2017) [8].

The concrete roadbed and the track slab are the elements of the China Railway Track System I (CRTS I) [9]. The ballastless slab track system comprises of reinforced concrete substrate, pre-stressed concrete track slab and ductile mortar injected between roadbed and track slab. The CRTS II (Chinese rail transit summit type II) ballastless slab track on the subgrade comprises of rail, fastening system, track slab, ductile mortar layer and concrete supporting layer. Ductile mortar layer is used as a filling layer between track slab and concrete supporting layer for load transfer and buffer action [10-13].

Concrete slab can be made in-situ. Accordingly fresh concrete of high workability should be used $[14,15]$. It is necessary to strictly control the workability of the mixture to ensure the required quality of concrete in the structure [16-20].

There are several factors that affect the fresh concrete workability: water demand and composition of Portland cement, properties of fine and coarse aggregates, presence of superplasticizer etc. [21-23]. Enhancing the fresh concrete workability using mineral additives was shown in papers [24-26]. The increase of superplasticizer effect by some mineral additives is stated in the papers [27-29]. Russian regulations prohibit the use of mineral additives in the railway concrete sleepers. Accordingly the use of ground quartz for a monolithic concrete slab requires justification.

The compositions of fresh concrete with high-fluidity for concrete slab should be developed. At the same time the mixtures must have low water demand and low amount of expensive superplasticizer. The aim of the paper is to study the influence of quantity and fineness of ground quartz additives as well as superplasticizer amount on workability of fresh concrete. These allow reduce the expensive components of concrete mixture and increase the properties of fresh and hardened concrete.

\section{Materials and methods}

The fine and coarse aggregates used for sleepers production were chosen. Grain composition of two fine aggregates is presented in Table 1. The chemical compositions are presented in Tables 2. Ordinary Portland cement and mineral additive as ground sand (named sand 1 and 2) were chosen. The particle size distributions of ground quartz obtained with analyzer "Analysette 22" are presented in Table 3. The Portland cement was consistent with the requirements of cements for the transport construction. The polycarboxylate-based superplasticizer was chosen.

Table 1. Grain composition of sand

\begin{tabular}{|l|l|l|}
\hline \multirow{2}{*}{ Sieve size, mm } & \multicolumn{2}{|l|}{ Full remainders on the sieve, \% } \\
\cline { 2 - 3 } & sand 1 & sand 2 \\
\hline 2.5 & 8.5 & 5 \\
\hline 1.25 & 20.5 & 21 \\
\hline 0.63 & 68.5 & 50.5 \\
\hline 0.315 & 88.5 & 82.2 \\
\hline 0.16 & 97.7 & 95.2 \\
\hline$<0.16$ & 100 & 99.2 \\
\hline Fineness modulus of sand & 2.84 & 2.54 \\
\hline
\end{tabular}


Table 2. The chemical compositions of sand

\begin{tabular}{|l|l|l|l|l|l|l|l|l|}
\hline & $\mathrm{SiO}_{2}$ & $\mathrm{AI}_{2} \mathrm{O}_{3}$ & $\mathrm{Fe}_{2} \mathrm{O}_{3}$ & $\mathrm{CaO}$ & $\mathrm{MgO}$ & $\mathrm{K}_{2} \mathrm{O}$ & $\mathrm{Na}_{2} \mathrm{O}$ & L.O.I \\
\hline $\begin{array}{l}\text { sand 1 } \\
\text { feldspar }\end{array}$ & 65.74 & 8.67 & 3.97 & 7.10 & 5.47 & 3.00 & 5.20 & 0.85 \\
\hline $\begin{array}{l}\text { sand 2a } \\
\text { quartz }\end{array}$ & 97.85 & 0.03 & 0.09 & 1.1 & 0.93 & - & - & - \\
\hline $\begin{array}{l}\text { sand 2b } \\
\text { quartz }\end{array}$ & 97.85 & 0.03 & 0.09 & 1.1 & 0.93 & - & - & - \\
\hline
\end{tabular}

Table 3. The particle size distributions of ground sand

\begin{tabular}{|l|l|l|l|l|}
\hline \multirow{2}{*}{} & \multicolumn{4}{|c|}{ The quantity of particles with size less then, \% } \\
\cline { 2 - 5 } & $1 \mu \mathrm{m}$ & $5 \mu \mathrm{m}$ & $10 \mu \mathrm{m}$ & $50 \mu \mathrm{m}$ \\
\hline sand 1 & 3.9 & 26.5 & 39.1 & 90.1 \\
\hline sand 2a & 4.7 & 21.9 & 40.5 & 87.2 \\
\hline sand 2b & 6.2 & 39.8 & 57.2 & 98.7 \\
\hline
\end{tabular}

The composition of B40 concrete strength class is used for sleepers production as shown in Table 4.

Table 4. The concrete composition

\begin{tabular}{|l|l|l|l|l|l|l|l|}
\hline \multirow{2}{*}{$\begin{array}{l}\text { Workability } \\
\text { of zero } \\
\text { slum, s. }\end{array}$} & \multirow{2}{*}{ W/C } & \multicolumn{3}{|l|}{ Расход на 1 куб.м, кг } & Compo- & $\begin{array}{l}\text { Superplas- } \\
\text { ticizer, \% }\end{array}$ & $\begin{array}{l}\text { Density, } \\
\mathrm{kg} / \mathrm{m}^{3}\end{array}$ \\
\cline { 3 - 8 } & & Cement & Sand & $\begin{array}{l}\text { Coarse } \\
\text { aggregate }\end{array}$ & & & \\
\hline $11-20$ & 0.35 & 450 & 645 & 1160 & $1: 1.43: 2.58$ & - & 24 \\
\hline
\end{tabular}

Superplasticiser and ground sand were added in composition and the properties of fresh mixture (slump) and hardened concrete (compressive strength at the age of 24 hours, 28 and 360 days) were estimated.

\section{Results and discussion}

Correlations among slump flow, superplasticizer quantity and sand type are shown in Fig. 1.

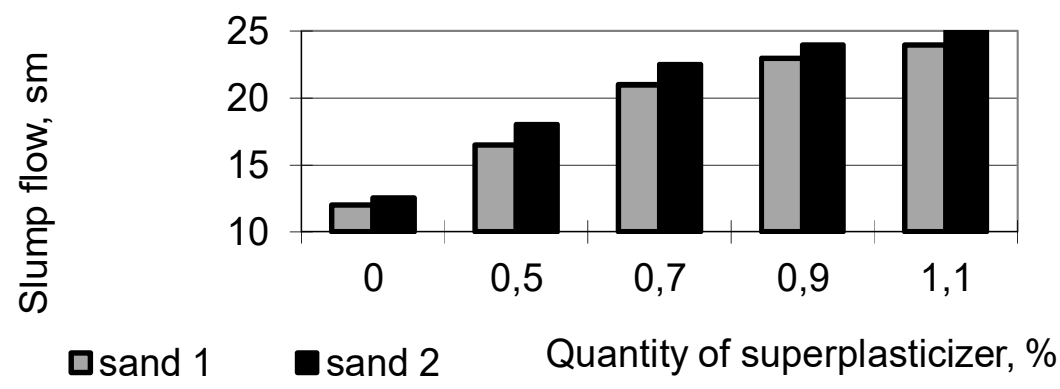

Fig 1. Correlations among slump flow, superplasticizer quantity and sand type

From the analysis of Fig. 1 it can be concluded that the type of sand has an effect on the slump of fresh concrete with a superplasticizer. However, the slump of mixtures without superplasticizer but differing in the sand type is almost the same. The situation differs in mixtures with a superplasticizer. Sand 2 (quartz sand) significantly increases the plasticizer effect. Thus, the correct choice of the type of sand as a fine aggregate allows increasing the workability of mixtures. 
It can be assumed that the mineral additives obtained by grinding the corresponding sands will also be able to increase the plasticizer effect.

Farther the influence of quantity of superplasticizer as well as the quantity and dispersion of ground quartz sand on the slump of fresh concrete was studied with big cone (Fig.2-3).

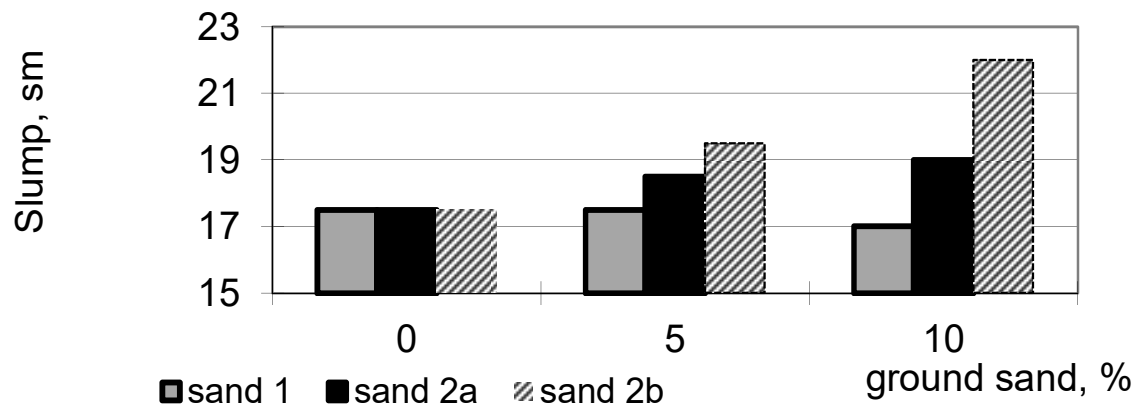

Fig 2. Correlations among slump flow, type, quantity and fineness of ground sand (superplasticizer in amount of $0.5 \%$ of Portland cement mass)

The ground quartz sand (sand $2 \mathrm{a}$ and $2 \mathrm{~b}$ ) in quantity of $10 \%$ of Portland cement mass can significantly increase the slump value of fresh concrete as shown in Fig.2. Accordingly the superplasticizer amount does not need to increase. The ground sand 1 does not influence on the slump value of fresh concrete.

Experiments with small changes in the quantity of superplasticizer and mineral additive in the amount of $5-10 \%$ have showed that it is possible to save $0.1 \%$ of superplasticizer in 1 $\mathrm{m}^{3}$ of fresh concrete keeping the same workability. Portland cement was replaced partially with ground quartz sand. Compressive strength of concrete with ground quartz sand in the amount of $5 \%$ has corresponded to reference concrete at the age of 24 hours, 28 and 360 days.

The slab of $6450 \mathrm{~mm} \times 2550 \mathrm{~mm} \times 200 \mathrm{~mm}$ size was chosen to calculate the savings of superplasticizer in case of reduction of $0.1 \%$ superplasticizer. Savings of superplasticizer per $1 \mathrm{~m}^{3}$ of concrete one can calculate. For example it is necessary to take $450 \mathrm{~kg}$ of Portland cement per $1 \mathrm{~m}^{3}$ of concrete.

$$
\mathrm{Q}=450: 100 \times 0.1=0.45(\mathrm{~kg})
$$

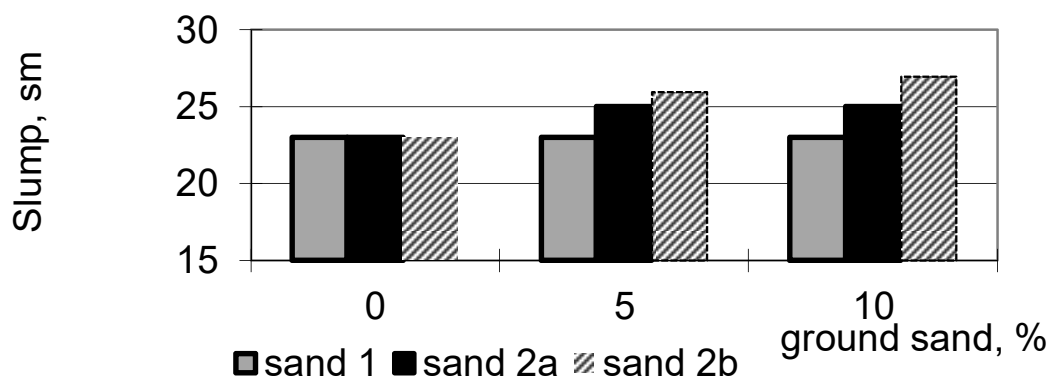

Fig 3. Correlations among slump flow, type, quantity and fineness of ground sand (superplasticizer in amount of $0.7 \%$ of Portland cement mass)

The dimensions of the concrete slab are $6450 \mathrm{~mm} \times 2550 \mathrm{~mm} \times 200 \mathrm{~mm}$, so the volume of 
concrete required for the manufacture of this slab will be:

$$
\mathrm{v}=6.45 \times 2.55 \times 0.2=3.2895\left(\mathrm{~m}^{3}\right)
$$

The number of plates required for $1 \mathrm{~km}$ of the ballastless track will be:

$$
\mathrm{N}=1000: 6.45 \approx 155 \text { (slabs) }
$$

The volume of concrete required for $1 \mathrm{~km}$ of the ballastless track will be:

$$
\mathrm{V}=3.2895 \times 155 \approx 509\left(\mathrm{~m}^{3}\right)
$$

Savings of superplasticizer for $1 \mathrm{~km}$ of the ballastless track will be:

$$
\mathrm{S}=509 \times 0.45=229.1(\mathrm{~kg})
$$

The cost of mineral additive was not taken into account since it was added instead of Portland cement mass.

One can conclude that the ground quartz sand use increases the superplasticizer effect and can give savings of admixture. The use of ground quartz sand for critical transport structures requires further study. Analysis of Fig. 2-3 shows that plasticizer effect depends on the type, fineness and quantity of ground sand in the concrete compositions.

\section{Summary}

The compositions of high-fluidity fresh concrete with low quantity of polycarboxylatebased superplasticizer are developed. The correct choice of the type of sand as a fine aggregate allows increasing the workability of mixtures with polycarboxylate-based superplasticizer. The greatest improvement was obtained using quartz sand.

It has been found that the increase of plasticizer effect depends on the type of ground sand as well as on their quantity and fineness. The ground quartz sand in quantity of $10 \%$ of Portland cement mass can significantly increase the slump value of fresh concrete. Influence of the fineness and quantity of the ground quartz on workability of fresh concrete mixtures was shown. The results of the research can be recommended for high performance concrete of ballastless track slabs.

\section{References}

1. B. Indraratna, M.B. Sajjad et al., Transportation Geotechnics, 100260 (2019). doi.org/10.1016/j.trgeo.2019.100260

2. Y. Yang, G. Wu. Magazine of Concrete Research, 72(1), 43-54 (2020). doi.org/10.1680/jmacr.18.00179

3. L. Diachenko, A. Benin et al., Civil and Environmental Engineering, 14(1), 37-43 (2018). doi.org/10.2478/cee-2018-0005

4. L. Diachenko, Benin, A. et al., IOP Conference Series: Materials Science and Engineering 463(2), 022048 (2018). doi.org/10.1088/1757-899X/463/2/022048

5. D.A.I. Gong-lian, G. E. Hao, Journal of Railway Engineering Society, 7, 5 (2018).

6. H. Jiang, X. Li et al., Transportation Geotechnics, 18, 103-110 (2019). doi.org/10.1016/j.trgeo.2018.10.007

7. L. Diachenko, A. Benin E3S Web of Conferences, 135, 03065 (2019). doi.org/10.1051/e3sconf/201913503065

8. Rheda 2000. Broschueren. Information on: http://www.railone.com/fileadmin/daten/05presse-medien/downloads/broschueren/en/Rheda2000_EN_2011_ebook.pdf

9. X. H. Zeng, Y. J. Xie et al., Construction and Building Materials, 112, 93-99 (2016). doi.org/10.1016/j.conbuildmat.2015.08.024 
10. P. Wang, H. Xu, R. Chen, Advances in materials science and engineering, (2014). doi.org/10.1155/2014/193128

11. A. V. Benin, A. S. Semenov et al., Magazine of Civil Engineering, 77(1), 279-297 (2018) doi.org/10.18720/MCE.76.24

12. K. Lavrov, A. Semenov, A. Benin, MATEC Web of Conferences, 53, 01043 (2016). doi.org/10.1051/matecconf $/ 20165301043$

13. A. Benin, S. Nazarova, A. Uzdin Energy Management of Municipal Transportation Facilities and Transport 600-610 (2018). doi.org/10.1007/978-3-030-19868-8_57

14. L.F. Kazanskaya, V.I. Isakovsky, S.A. Fadeeva. International Journal of Innovative Technology and Exploring Engineering (IJITEE). 8(12), 799-803 (2019). DOI: 10.35940/ijitee.L3212.1081219

15. A. Lobiak, A. Plugin et al., Matec Web of Conferences, 234, 04004 (2018). doi.org/10.1051/matecconf/201823404004

16. N. Roussel, A. Gram et al., Cement and Concrete Research, 79, 265-271 (2016). doi.org/10.1016/j.cemconres.2015.09.022

17. V. Mechtcherine, J. Grafe et al., Construction and Building Materials, 179, 125-137 (2018). doi.org/10.1016/j.conbuildmat.2018.05.202

18. V. Mechtcherine, S. Shyshko, Cement and Concrete Composites, 55, $81-90$ (2015). doi.org/10.1016/j.cemconcomp.2014.08.004

19. E. Secrieru, S. Fataei et al., Construction and Building Materials, 144, 451-461 (2017). doi.org/10.1016/j.conbuildmat.2017.03.199

20. E. Secrieru, W. Mohamed et al., Cement and Concrete Composites, 107, 103495 (2020). doi.org/10.1016/j.cemconcomp.2019.103495

21. A. M. Kharitonov, Y. M. Tikhonov, Y. A. Belentsov. Geotechnics Fundamentals and Applications in Construction: New Materials, Structures, Technologies and Calculations (2019).

22. O.M. Smirnova, Procedia Engineering, 172, 1039-1043 (2017). doi: 10.1016/j.proeng.2017.02.158

23. V.I. Ochkurov, M.Y. Vilenskii. IOP Conference Series: Materials Science and Engineering 666 (1), 012026 (2019). doi.org/10.1088/1757-899X/666/1/012026

24. O. Palant, D. Plugin et al., MATEC Web of Conferences, 230, 03014 (2018). doi.org/10.1051/matecconf/201823003014

25. A.A. Plugin, D. A. Plugin et al., Current Issues of Civil and Environmental Engineering 346-353 (2019). doi.org/10.1007/978-3-030-27011-7_44

26. J. Sliseris, A. Korjakins. Mechanics of Composite Materials, 55(1), 29-40 (2019). doi.org/10.1007/s11029-019-09789-x

27. M. Macijauskas, G. Skripkiūnas Solid State Phenomena, 276 27-34 (2018). doi.org/10.4028/www.scientific.net/SSP.276.27

28. O.M. Smirnova. Magazine of Civil Engineering, 6, 12-22 (2016).

29. O.M. Smirnova International Journal of Civil Engineering and Technology, 9(10) 19661973 (2018). 